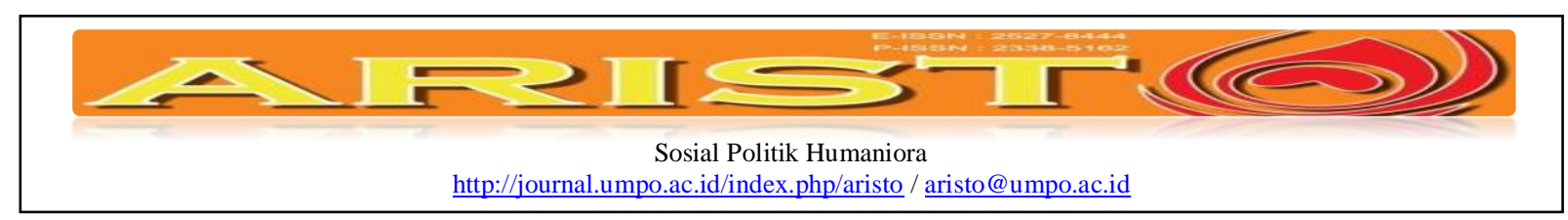

\title{
Peningkatan Pendapatan Daerah Berbasis Pada Usaha Mikro, Kecil, Dan Menengah
}

\author{
Khairina Nainggolan, Yaqub Cikusi, Hayat \\ Program Studi Ilmu Administrasi Publik \\ Fakultas Ilmu Administrasi Universitas Islam Malang \\ Nai.ng@yahoo.com, hayat.150318@gmail.com
}

\begin{abstract}
The development of small and micro enterprises have a very important role in the development of the regional economy. it can be seen from the amount of employment opportunities provided by UMKM for the community. UMKM existence cannot be under timed, because UMKM have a proven able to with stand the economic crisis that occurred in Indonesia. However, in the development of UMKM cannot be separated from in habiting fact that hit existence of UMKM. Several classic problems that occur in UMKM is lack of capital in the developing the business, unhealthy market competition that still happening until now is the market competition with product made in china. Lack of information about the market network and still lack of innovation in creating new product-products. UMKM therefore very much require the role of government in the developing small andmiddlebusiness.
\end{abstract}

Keywords: UMKM, UMKM development; Regional income.

\begin{abstract}
Abstraksi
Perkembangan Usaha Mikro Kecil dan Menengah(UMKM) memilki peran yang sangat penting dalam pembangunan perekonomian daerah.Hal ini dapat dilihat dari besarnya peluang pekerjaan yang disediakan oleh UMKM bagi masyarakat.Dimana tujuan dari UMKM adalah untuk memajukan perekonomian daerah.Keberadaan UMKM tidak bisa dianggap remeh, dikarenakan UMKM telah terbukti mampu bertahan terhadap krisis ekonomi yang terjadi di Indonesia.Namun dalam perkembangan UMKM tidak lepas dari faktor penghambat yang melanda keberadaan UMKM. Beberapa permasalahan klasik yang terjadi di UMKM adalah kurangnya modal dalam menggembangkan usaha tersebut, persaingan pasar yang tidak sehat antara pengrajin UMKM dan persaingan pasar yang masih terjadi sampai saat ini yaitu persaingan dengan produk buatan cina. Kurangnya informasi tentang jaringan pasar serta masih kurangnya inovasi dalam menciptakan produk-produk baru.Olehkarena itu UMKM sangat memerlukan peran pemerintah dalam mengembangkan Usaha Mikro kecil dan Menengah.
\end{abstract}

Kata Kunci: UMKM; Pengembangan UMKM; Pendapatan Daerah

\begin{tabular}{|ll}
\hline Submite & $:$ 21 Jan 2017 \\
Review & $:$ 25 April 2017 \\
Accepted & $:$ 25 Mei 2017 \\
Surel Corespondensi & $:$ ayubdwianggoro86@gmail.com
\end{tabular}

Khairina Nainggolan, Yaqub Cikusi, Hayat, Peningkatan Pendapatan Daerah Berbasis Pada Usaha Mikro, Kecil, Dan Menengah /09/Vol. 05/No. 02 Juni 2017 


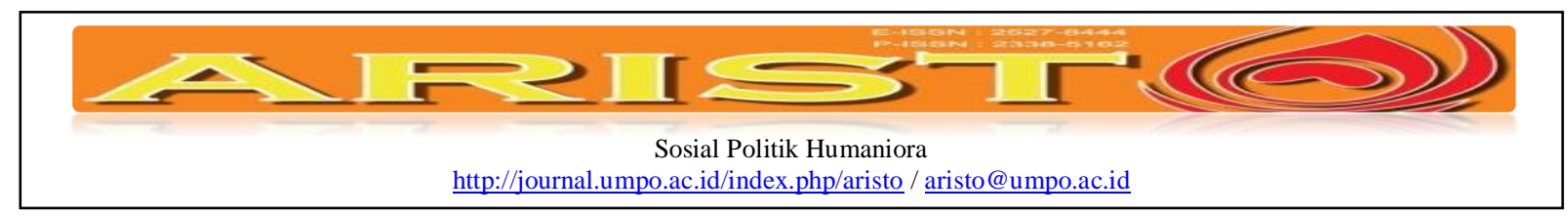

\section{Pendahuluan}

Permasalahan ekonomi yang terjadi di Indonesia merupakan hal yang belum dapat terselesaikan oleh pemerintah.Hal ini terjadi dikarenakan masih banyaknya masyarakat yang tidak memiliki pekerjaan. Terutama yang terjadi pada krisis ekonomi yang melanda Indonesia. Banyak para karyawan yang di PHK oleh para pemilik perusahaan besar.Dampak yang disebabkan dari krisis ekonomi ini adalah banyak perusahaan besar yang bangkrut.akibatnya semakin besarnya angka pengangguran yang juga menagkibatkan banyaknya kemiskinan. Namun pada krisis ekonomi tersebut sebagian usaha tidak memiliki dampak negative dan masih mampu bertahan.Usaha tersebut adalah Usaha Mikro Kecil dan Menengah.UMKM merupakan kegiatan yang dapat membantu perekonomian suatu daerah. Adanya UMKM bukan saja hanya meningkatkan penghasilan tetapi juga meratakan pendapatan di daerah tersebut. Ini dapat dilihat karena UMKM melibatkan banyak orang dan menghasilkan beragam usaha. UMKM merupakan urat nadi perekonomian daerah. Sesuai dengan undang-undang 20 tahun 2008 tentang usaha Mikro, kecil dan menengah (UMKM) menyebutkan pengertian UMKM dibagi menjadi tiga yaitu Usaha Mikro adalah suatu usaha produktif milik perorangan dan atau badan usaha perorangan yang memenuhi kriteria usaha mikro sebagaimana diatur dalam undang-undang ini.

Usaha kecil adalah usaha ekonomi produktif yang berdiri sendiri, yang dilakukan oleh orang perorangan atau badan usaha yang bukan merupakan anak perusahaan atau bukan cabang perusahaan yang dimiliki, dikuasai, atau menjadi bagian baik langsung maupun tidak langsung dari usaha menengah atau usaha besar yang memenuhi kriteia usaha kecil sebagaimana yang di atur dalam undang-undang ini. Sedangkan Usaha menengah adalah usaha ekonomi produktif yang berdiri sendiri, yang di lakukan oleh orang-perorang atau badan usaha yang bukan merupakan anak perusahaan atau cabang perusahaan yang di miliki, dikuasai, atau menjadi bagian baik langsung maupun tidak langsung. Usaha mikro, kecil dan menengah memiliki tujuan untuk menumbuhkan dan mengembangkan usahanya dalam rangka membangun perekonomian nasional berdasarkan demokrasi ekonomi yang berkeadilan.

Usaha Mikro Kecil dan Menengah ini merupakan peran penting dalam membantu perkembangan perekonomian daerah,selain itu Usaha mikro, kecil, dan menengah telah menjadi tulang punggung perekonomian Indonesia. Sejarah membuktikan ketika tejadinya krisis moneter 


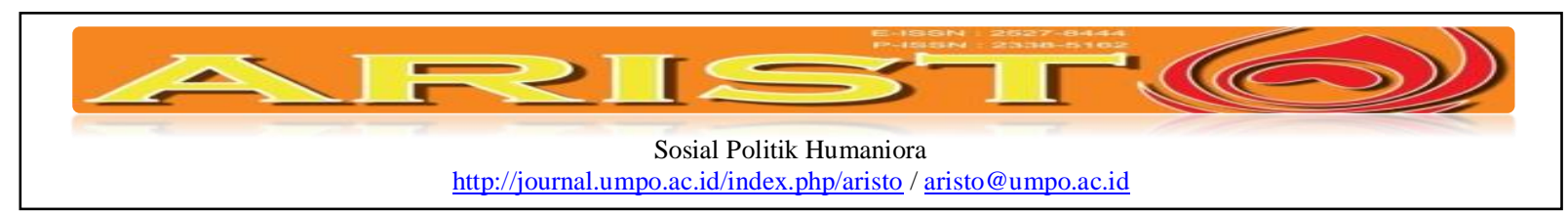

di tahun 1997.Hal ini dikarenakan UMKM dapat memberikan lapangan pekerjaan bagi masyarakat dan juga mampu memberikan kesempatan kepada masyarakat untuk memajukan daerahnya.Dikarenakan UMKM ini masih memilki ciri-ciri yaitu merupakan usaha milik keluarga, masih menggunakan teknologi tenaga manusia, dan masih memiliki jiwa persaudaraan.Seperti halnya yang terjadi di UMKM sentra kerajinan keramik dinoyo.sebagian besar para pengrajin keramik dan karyawan di UMKM sentra kerajinan keramik berasal dari daerah Dinoyo dan sekitarnya. Ini merupakan bukti bahwa UMKM dapat menjadi peluang usaha dan peluang pekerjaan bagi masyarakat disekitarnya.Hal ini dapat mendorong pendapatan daerah.

Pengembangan UMKM di sentra kerajinan keramik dinoyo tidak lepas dari permasalahan-permasalahan yang menjadi penghambat pelaksanaan UMKM.Permasalahan yang terjadi pada UMKM merupakan permasalahan klasik yang harus dihadapi. Permasalahannya antara lain adalah permasalahan kurangnya sarana dalam memasarkan produk. Hal ini berkaitan dengan berapa banyak produk yang akan dipasarkan. Pengrajin UMKM masih belum dapat memahami jaringan pasar mana yang akan ditembus. Sehingga produk yang akan di pasarkan sebagian besar masih daerah lokal saja dan para pembeli masih sekitar daerah saja, walaupun sudah ada beberapa yang sudah dipasarkan keluar kota.

Permasalahan lainnya yaitu persaingan pasar yang masih menjadi permasalahan umum yang terjadi di UMKM.Hal ini dikarenakan kurangnya pengetahuan para pengrajin UMKM tentang strategi pemasaran dan strategi pasar.sehingga masih belum dapat bersaing dengan produk-produk luar terutama produk cina. Dimana produk-produk cina sangat menarik perhatian para pembeli hal ini dikarenakan produk buatan cina memiliki harga yang jauh lebih murah dibandingkan dengan produk lokal, dan para pengrajin produk cina memiliki strategi pemasaran, dan juga memiliki berbagai ide-ide kreatif dalam mendesain produknya.

Berbeda dengan produk-produk lokal yang dimiliki oleh Indonesia kebanyakan produk Indonesia masih kurang memiliki ide-ide kreatif untuk mendesain produk mereka.Kurangnya pelatihan yang dilakukan oleh paguyuban kerajinan keramik Dinoyo merupakan dasar dari permasalahan tersebut.paguyuban dibuat hanya sebagai formalitas dari adanya UMKM tersebut, kurangnya kesadaran dari pengurus paguyuban tersebut sehingga kurang optimalnya perkembangan UMKM. 


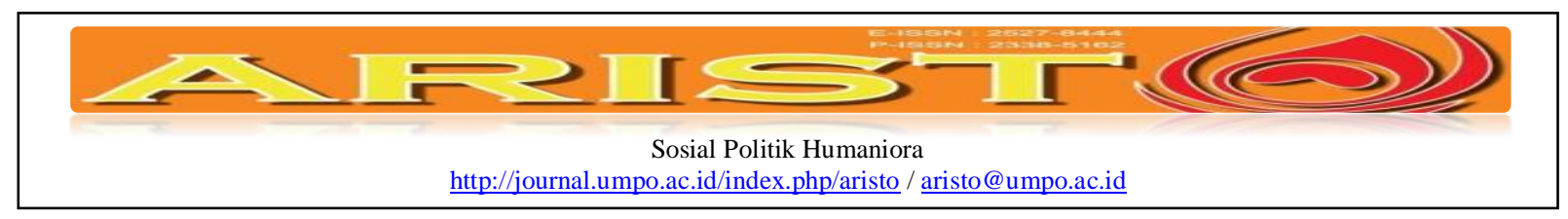

Pada dasarnya paguyuban dibuat untuk menampung ide-ide kreatif untuk mengembangkan produk dan memberikan pelatihan-pelatihan untuk meningkatkan daya saing produk terhadap produk lainnya.Permasalahan selanjutnya yang paling klasik adalah masalah permodalan.Modal adalah bagian terpenting untuk mengembangkan UMKM.Nyatanya dilapangan untuk mendapatkan pinjaman modal para pengrajin masih kesulitan untuk mendapatkannya.Modal yang didapat oleh para pengrajin hampir seluruhnya berasal dari modal sendiri.sehingga para pengrajin masih kurang mengembangkan usahanya dikarenakan seringnya menyatukan modal usaha dengan keperluan sehari-hari. Selanjutnya permasalan berikutnya adalah kurangnya strategi .Strategi dalam menjalankan suatu usaha sangatlah penting, salah satunya adalah tempat usaha. Tempat usaha merupakan penentu keberhasilan dalam memasarkan produk tersebut. Lokasi bisnis yang strategis merupakan incaran bagi para wirausahawan untuk menjual produknya. Namun dalam hal ini, peneliti melihat kurang strategisnya tempat usaha yang ada di UMKM sentra kerajinan keramik dinoyo tersebut. Menurut peneliti tempat yang di jadikan tempat usaha oleh para pengrajin terlalu sempit. Tempat pemasaran UMKM yang di jual di rumah-rumah mengakibatkan kurang adanya lahan untuk parkir sehingga mengakibatkan kurangnya konsumen.Dari permasalahan diatas peneliti ingin mengetahui tentang bagaimana peranan usaha mikro kecil dan menengah terhadap pertumbuhan ekonomi daerah.

\section{Metode dan Kajian Pustaka}

Secara umum metode penelitian diartikan sebagai cara ilmiah untuk mendapatkan data dengan tujuan dan kegunaan tertentu.Metode penelitian ini menggunakan metode penelitian pendekatan kualitatif dimana di dalamnya menggunakan teknik-teknik pengumpulan data utama yang terdiri atas tiga teknik yaitu pengamatan, wawancara yang mendalam dan dokumentasi. Menurut Furchan (2007), adalah strategi umum yang dianut dalam pengumpulan dan analisis data yang diperlukan guna menjawab persoalan yang dihadapi. Metode penelitian ini digunakan sebagai alat untuk memecahkan masalah .batasan masalah dalam penelitian kualitatif disebut sebagai focus, yang berisi pokok masalah yang masih bersifat umum. Dalam mempertajam penelitian, peneliti menetapkan focus. 


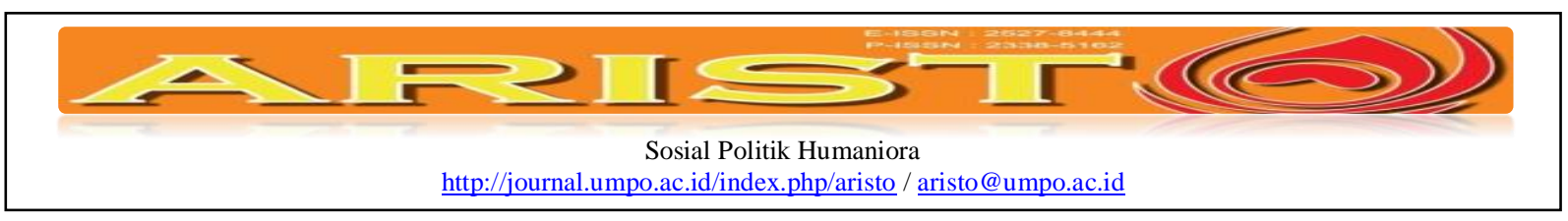

Spradley dalam sugiyono (2012) mengemukakan ada empat alternative untuk menetapkan focus penelitian.Yaitu : (1). Meetapkan focus pada permasalahan yang disarankan oleh informan, (2).Menetapkan fokus berdasarkan domain-domain tertentu, (3).Menetapkan fokus yang memiliki nilai temuan untuk mengembangkan iptek, (4).Menetapkan fokus berdasarkan permasalahan yang terkait dengan teori-teori yang telah ada. Seperti penelitian kali ini fokus penelitiannya, yaitu: mengidentifikasi dan menggambarkan peranan Usaha Mikro Kecil Menengah (UMKM) terhadap pertumbuhan ekonomi daerah sentra industry keramik Kelurahan Dinoyo Kecamatan Lowokwaru Kota Malang yang memiliki potensi sebagai sumber pendapatan asli daerah, memiliki potensi sebagai sumber lapangan pekerjaan bagi masyarakat sekitar UMKM, memliki potensi sebagai memajukan daerah dengan upaya dan strategiyang dilakukan masyarakat setempat untuk mengembangkan UMKM. Selain itu focus permasalahannya juga mengindentifikasi dan mengganalisis faktor-faktor yang mempengaruhi Peranan UMKM terhadap pertumbuhan ekomi daerah.

Penelitian ini dilaksanakan pada sentra kerajinan keramik dinoyo kelurahan dinoyo kecamatan lowokwaru kota malang dan paguyuban sentra kerajinan keramik serta masyarakat sekitar lokasi, dan yang menjadi sumber datanya berasal dari masyarakat sekitar daerah UMKM Dinoyo. Masyarakat Dinoyo pertahunnya mengalami peningkatan pendapatan, Hal ini dapat dilihat dari Laporan Akuntabilitas Kinerja Instansi Pemerintah (LAKIP) Kota Malang pada tahun 2013 memiliki pendapatan asli daerah sebesar Rp. 317.850.423.684,26. Sedangkan pada tahun 2014 mengalami kenaikan pendapatan asli daerah sebesar Rp. 372.550.096. 292,03. Pada tahun 2015 pendapatan asli daerah kota malang sebesar Rp. 424.937.346.938,06 .Dan pada pendapatan tahun 2016 pendapatan asli daerah mencapai Rp. 477.332.655.834,88. Pendapatan asli daerah tersebut terdiri dari hasil pajak daerah, hasil pengelolaan retribusi, dan hasil pengelolaan kekayaan daerah yag dipisahkan dari lain-lain. Hal ini juga tak lepas dari Peran UMKM. Seperti UMKM di Dinoyo pendapatan terbesar Asli daerahnya berasal dari kegiatan UMKM. Hal ini dapat dilihat dari mata pencaharian masyarakat sekitar UMKM memiliki pekerjaan sebagai wiraswasta/pedagang.

Menurut Moleong (2012), Sumber data utama dalam penelitian kualitatif menggunakan kata-kata, tindakan dan selebihnya adalah data tambahan seperti dokumen dan lainlainnya.Dalam penelitian ini adalah sumber data terbagi 2 yaitu sumber data primer dan sumber 


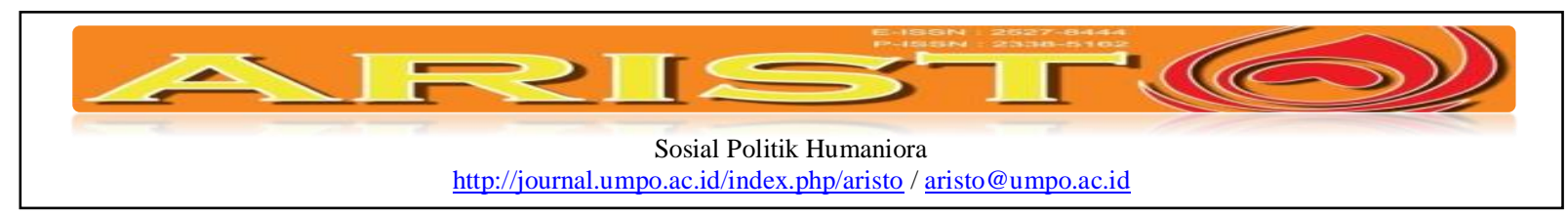

data sekunder. Sumber data primer adalah sumber data langsung yang diambil dari sumbernya yang asli yang memiliki informasi dan data. Sumber data primer dalam penelitian ini adalah para pengrajin keramik dinoyo, sedangkan sumber data sekunder adalah sumber data yang diperoleh secara tidak langsung dari sumbernya biasanya melalui perantara ataupun data yang dicatat oleh pihak lain. Selanjutnya, terdapat dua hal utama yang mempengaruhi kualitas data hasil penelitian yaitu, kualitas instrument penelitian dan kualitas pengumpulan data.Kualitas pengumpulan data berkenaan dengan ketepatan cara-cara yang digunakan untuk mengumpulkan data. Penggumpulan data dapat dilakukan dengan berbagai setting, sumber dan berbagai cara. Selanjutnya, Teknik pengumpulan data dalam penelitian ini menggunakan tiga teknik dasar yaitu dengan cara wawancara, observasi, dan dokumentasi. Seperti yang dikemukakan oleh Sutrisno (1986) bahwa dalam metode wawancara yaitu: (1). Bahwa subyek (responden) adalah orang yang paling tahu tentang dirinya sendiri, (2). Bahwa apa yang dikatakan oleh subyek kepada peneliti adalah benar dan dapat dipercaya, (3). Bahwa subyek tentang pertanyaanpertanyaan yang diajukan peneliti kepadanya adalah sama dengan apa yang dimaksudkan oleh peeliti.Pada penelitian ini menggunakan wawancara terstruktur dan tertutup.Dimana ketiga objek ini bertujuan untuk meggambarkan segala sesuatu yang berhubungan dengan penelitian seperti perkembangan, tingkah laku dan lain sebagainya tentang peranan UMKM serta mendapatkan data yang pasti dilapangannya.

Dalam penelitian Kualitatif, data diperoleh dari berbagai sumber, dengan menggunakan teknik pengumpulan data yang bermacam-macam, dan dilakukansecara terus menerus sampai datanya jenuh. Dengan pengamatan yang terus menerus tersebut mengakibatkan variasi data tinggi sekali. Menurut Susan Stainback dalam Sugiyono (2012) mengemukakan analisis data merupakan hal yang kritis dalam proses penelitian kualitatif. Analisis digunakan untuk memahami hubungan dan konsep dalam data sehingga hipotesis dapat dikembangkan dan dievaluasi. Pada Penelitian ini juga menggunakan teknik analisis data, adanya analisis data ini dapat menjadi upaya yang dilakukan dengan jalan bekerja dengan data, mengorganisasikan data, memilah-milahnya menjadi satuan yang dapat dikelola, mensintesiskannya, mencari dan menemukan pola, menemukan yang penting dan apa yang dipelajari.Teknik analisis data kualitatif pada penelitian ini menggunakan model analisis data interaktif yang dikembangkan oleh Miles dan Huberman (1994). Dimana model analisis data tersebut terdiri dari tiga alur 


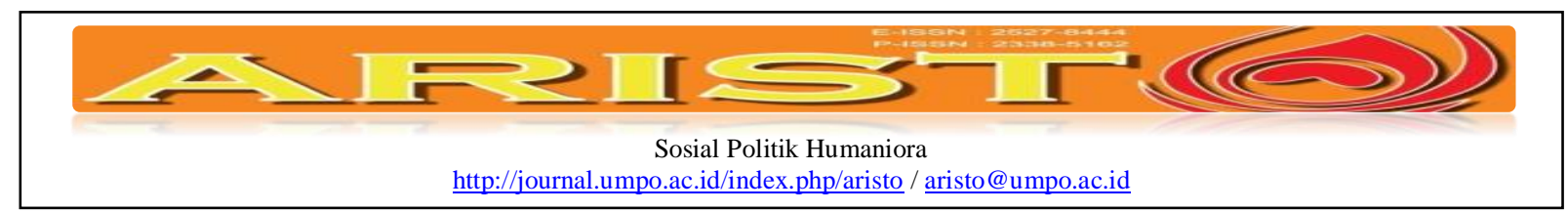

kegiatan yang terjadi secara besamaan, yaitu: Reduksi data, Penyajian data, dan Penarikan kesimpulan/verifikasi. Data yang diperoleh dari lapangan jumlahnya cukup banyak untuk itu maka perlu dicatat secara teliti. Mereduksi data merupakan peneliti merangkum, memilih hal-hal pokok, menfokuskan pada hal-hal yang penting, dan menbuang data apabia tidak penting. Selanjutnya menyajikan data yaitu berupa data yang diuraikan singkat, dengan bagan. Tujuannya untuk memudahkan untuk dipahami apa yang terjadi, dan merencanakan kerja selanjutnya berdasarkan apa yang telah dipahami. Langkah selanjutnya yaitu menarik kesimpulan.

Ketiga kegiatan tersebut merupakan kegiatan yang menjalin pada saat sebelum, selama, dan sesudah pengumpulan data dalam bentuk yang sejajar untuk membangun wawasan umum yang disebut analisis. Pengumpulan data ini terdiri dari kegiatan wawancara, observasi dan dokumentasi yang telah dijelaskan sebelumnya. Reduksi data dimaksudkan sebagai proses pemilihan, pemusatan perhatian pada penyederhanaan, pengabsahan dan tranformasi data kasar yang muncul dari catatan tertulis dilapangan. Dan penyajian data dimaksudkan sebagai sekumpulan imformasi tersusun yang memberikan kemungkinan adanya penarikan kesimpulan dan pengambilan tindakan baik peyajian data bentuk tabel maupun naratif yang menggambungkan informasi yang tersusun kedalam bentuk yang terpadu.

Pendekatan Penelitian yang dilakukan pada UMKM sentra kerajinan Keramik dinoyo berdasarkan dengan apa yang dilakukan oleh para pelaku UMKM. Seperti yang diungkapkan pada teori pertumbuhan ekonomi klasik menurut pandangan ahli-ahli ekonomi klasik ada 4 faktor yang mempengaruhi pertumbuhan ekonomi yaitu: jumlah penduduk, jumlah stok barangbarang dan modal, Luas tanah dan kekayaan alam serta tingkat tekonologi yang digunakan. Maka perubahan ekonomi UMKM Keramik Dinoyo dapat meningkat lebih baik berdasarkan 4 faktor tersebut. dari tahun ke tahun terjadinya peningkatan pendapatan melalui jumlah penduduk.berdasarkan data dari Monografi Kelurahan Dinoyo 2016 mengatakan di Kelurahan Dinoyo Masyarakat yang telah bekerja sebanyak 9.459 jiwa dan sebagian besar memiliki pekerjaan sebagai wiraswasta/pedagang sebanyak 6.511 jiwa hal ini dikarenakan besarnya peluang usaha dari kegiatan UMKM keramik dinoyo tersebut. Pada era modern ini telah mempermudah para usaha untuk meningkatkan pendapatannya melalui teknologi, seperti halnya beberapa para pelaku UMKM sentra kerajinan keramik juga telah memanfaatkan teknologi sebagai cara untuk meningkatkan pendapatannya. 


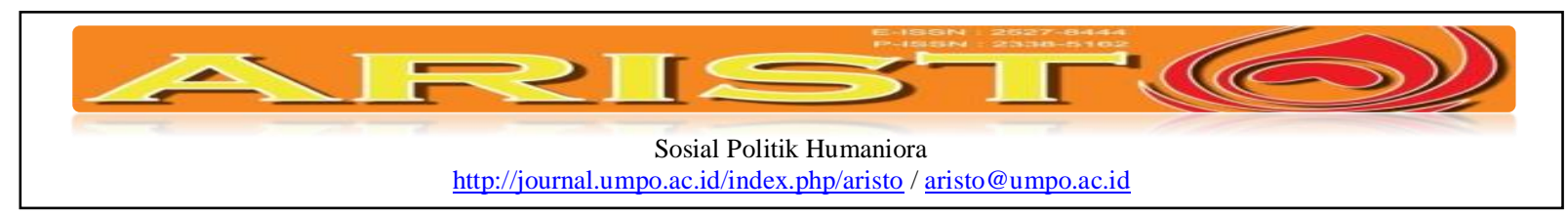

Pembahasan dan Analisis

Kota Malang Merupakan Kota terbesar kedua di Jawa Timur setelah Surabaya. Kota Malang memiliki cita-cita yang disebut sebagai Tri Bina Cita Kota Malang yaitu Malang sebagai Kota pendidikan, Malang sebagai Kota Industri dan Malang sebagai Kota Pariwisata. Sebagai Kota Industri yang, Kota Malang memiliki pola pertumbuhan Industri yang unik, dimana sebagian besar industrinya disokong oleh sektor Industri Kecil dan Mikro. Salah satu Industri unggulan kota malang adalah Industri keramik dan gerabah yang berada di kelurahan dinoyo dan kelurahan pananggunan Kota Malang.

Sejarah Industri Keramik di Kota Malang dimulai pada tahun 1953 saat pembentukan Lembaga Penyelenggara Perusahaan-Perusahaan Industri Dapertemen Perindustrian (LEPPIN). Kemudian muncul perusahaan keramik percontohan di daerah-derah. Tahun 1957, LEPPIN mendirikan pabrik Keramik Dinoyo yang berada di Kota Malang di resmikan Wakil Presiden Moh. Hatta dengan Nama Ky 5. Pabrik keramik Dinoyo merupakan pilot project pengolahan keramik dengan memanfaatkan teknologi baru yang lebih maju pada sat itu, yait dengan system cetak tuang \& putar tekan. Produk yang dihasilkan antara lain : piring, cangkir, moci, basi, sehingga dikenal dengan pabrik piring. Tahun 1962 keramik dinoyo memproduksi barang setengah jadi. Pada tahun 1968 unit-unit memisah diri dari induk untuk mengembangan usahanya sendiri tetapi masih menggantung pembinaan dan suplay bahan baku dari induk. Seiring berjalannya waktu, pabrik keramik yang berlokasi di Dinoyo mengalami stagnasi dan akhirnya ditutup. Penyebab tutupnya pabrik masih menjadi misteri. Penutupan Industri keramik Dinoyo berdampak pada masyarakat sekitar yang bekerja sebagai pengrajin.

Banyak diantara mereka yang merintis Industri keramik skala rumah tangga yang tersebar di Kelurahan Dinoyo dan Kelurahan Pananggunan. Dan sekarang Industri rumah tangga berkembang menjadi sentra Industri keramik di Kota Malang dan dikenal oleh masyarakat luas. Perkembangan Industri Keramik Dinoyo tidak lepas dari keuletan pengrajin yang terus berinovasi terhadap produk-produk keramik yang dihasilkan. Ciri khas produk keramik Dinoyo terletak pada warna dan Desain naturalnya yang mencirikan Negara teropis. Produk-produk keramik dinoyo banyak dipasarkan di kota-kota besar seperti Surabaya, Jakarta, dan Medan. Kondisi tersebut memberikan dampak positif baik ekonomi, sosial, dan budaya kepada masyarakat sekitar Kelurahan Dinoyo khususnya pengrajin. Hal tersebut, menjadikan pemerintah 


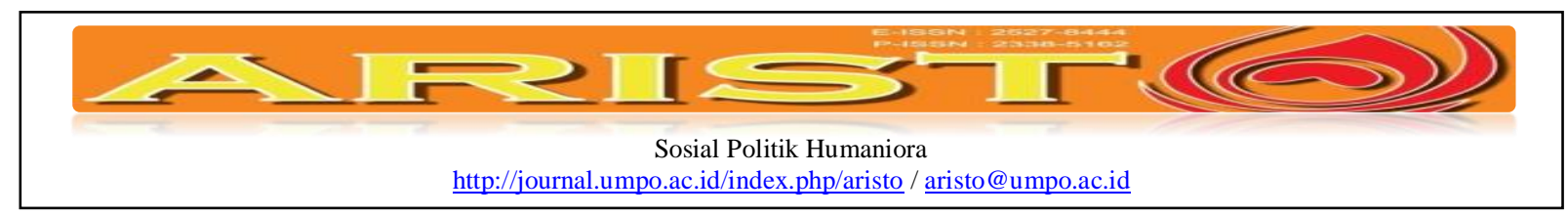

kota Malang menjadikan sentra kerajinan keramik Dinoyo menjadi wisata yang dikemas dengan konsep Kampung Keramik Dinoyo. Sebagian besar UMKM sentra kerajinan keramik Dinoyo telah berdiri sejak sebelum terjadinya krisis ekonomi.Hal yang melatar belakangi terbentuknya UMKM sentra kerajinan keramik dinoyo ini adalah untuk menciptakan peluang kerja bagi masyarakat dan yang paling utama adalah sebagai penopang pendapatan masyarakat.Menurut Kadariahh pendapatan adalah hasil-hasil yang diterima oleh masyarakat sebagai hasil jerih payah mereka selama bekerja, baik berupa barang atau pun berupa uang.

Besar kecilnya pendapatan setiap orang tidak sama disesuai kan dengan kemampuan dan keterampilan yang ia miliki, sehingga akan timbul suatu penghargaan terhadap kemampuan seseorang.Dengan adanya UMKM kerajinan keramik ini dapat memberikan dampak dalam meminimalisir angka penganguran yang ada di daerah dinoyo, dan dengan adanya sentra kerajinan keramik dinoyo ini dapat menambah pendapatan ekonomi daerah di Dinoyo dengan menciptakan lapangan pekerjaan baru. Dikarenakan sentra kerajinan keramik dinoyo dapat menjadi sumber pendapatan yang diminati oleh masyarakat dinoyo untuk melakukan kegiatan ekonominya.Sebagian besar karyawan dan pengrajin berasal dari daerah Dinoyo dan sekitarnya.

Hal ini juga dikarenakan kelurahan dinoyo merupakan tempat yang sering didatangi oleh para wisatawan.Produk-produk yang ada di UMKM kerajinan keramik ini bukan hanya keramik saja melainkan ada kerajinan yang dibuat dari gift sehingga tampilannya lebih menarik.Biasanya kerajinan keramik ini banyak diminati sebagai oleh-oleh da juga sebagai souvenir pengantin.UMKM kerajinan keramik Dinoyo termasuk kedalam sumber pendapatan yang berasal dari aktivitas utama. Hal ini dikarenakan kerajinan keramik dinoyo merupakan sumber pendapatan utama di daerah dinoyo seperti yang di ungkapkan oleh para narasumber bahwa sebagian besar masyarakat disekitar Dinoyo mendapatkan penghasilannya melalui kegiatan Kerajinan keramik.

Namun dalam perkembangannya UMKM tidak berjalan dengan mulus terdapat beberapa permasalahan yang terjadi diantaranya yaitu kurangnya strategi pemasaran penjualan produk keramik.Pemasaran yang digunakan disentra kerajinan keramik Dinoyo masih sangat tergolong sederhana. Hal ini dikarenakan para pengrajin masih belum menggunakan media terknologi untuk sistem pemasaran. Permasalahan lainnya yaitu susahnya mendapatkan modal, sebagian besar para pengrajin tidak dapat mengembangkan usahanya dikarenakan modal yang 


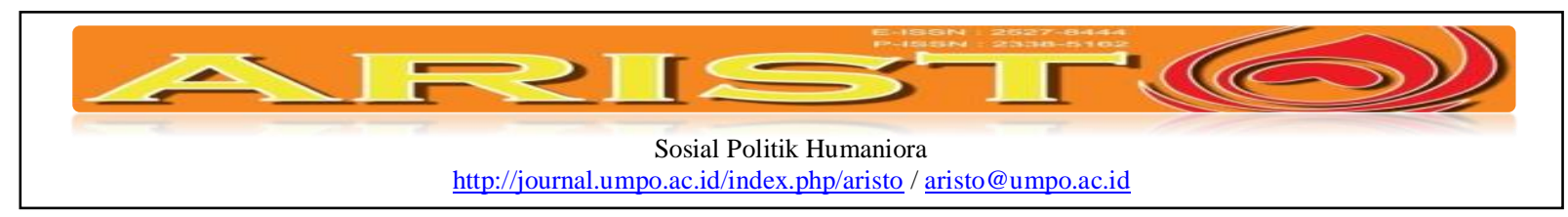

tersendat dan mengakibatkan penurunan produk yang dihasilkan.Modal usaha yang mereka miliki berasal dari modal usaha sendiri hal ini dikarenakan susahnya meminjam uang kepada pihak luar. Para pengrajin masih tidak dapat membedakan modal usaha dengan kebutuhan sehari-hari sehingga tidak dapat memutar modal untuk kebutuhan produksi selanjutnya.Permasalahan selanjutnya adalah permasalahan mengenai persaingan pasar.Persaingan pasar terjadi bukan hanya di luar saja melainkan juga terjadi dilokal.Persaingan pasar di luar yaitu persaingan pasar dengan produk china dan sebagainya dimana produk-produk cina ini diminati oleh masyarakat, dikarenakan harganya yang dapat terjangkau dan lebih rendah dari produk lokal dan juga desain dan bentuknya yang lebih menarik.Persaingan pasar lokal yang terjadi di UMKM sentra kerajinan keramik Dinoyo adalah dikarenakan para pengrajin masih ada yang bersaing secara tidak sehat.

Selain permasalahan diatas ada permasalahan yang terjadi lainnya yaitu permasalahan menegemen sumber daya manusianya, hal ini dikarenakan kurangnya ide-ide kreatif dalam menciptakan karya yang baru, maka dari itu diperlukannya pelatihan dari paguyuban yang ada ditempat.Berdasarkan papaaran diatas para pengrajin meminimalisir permasalahanpermasalahan dengan melakukan upaya-upaya untuk mengembangkan UMKM sentra kerajinan keramik agar dapat mencapai tujuannya yaitu sebagai tempat untuk membuka peluang usaha kerja dan menjadi sumber pendapatan ekonomi daerah.

Hal yang dilakukan para pengrajin UMKM sentra kerajinan keramik dinoyo adalah dengan memberdayakan sumber daya manusia agar dapat menciptakan berbagai macam produk yang mandiri dan dapat berdaya saing. Masyarakat harus di berdayakan agar nantinya dapat menciptakan produk-produk yang mempengaruhi kualitas barang dalam rangka dalam rangka menghasilkan peningkatan perekonomi masyarakat. Baik itu pemberdayaan melalui pelatihan agar dapat menciptakan ide-ide baru atau dengan meningkatkan kualitas barang dan juga pembekalan cara mempromosikan barang. Selain itu para pengrajin UMKM kerajiinan keramik Dinoyo mengupayakan Strategi pemasaran yang menarik perhatian para pembeli, salah satunya dengan mempertahankan kualitas barang yang akan dipasarkan. Selain itu dengan cara mengikuti event-event untuk mengenalkan produk-produk hasil karyanya.Sehingga peran UMKM sentra kerajinan keramik dinoyo dapat terealisasi sebagai pemberi peluang usaha dan juga peluang sebagai pendapatan ekonomi daerah. 


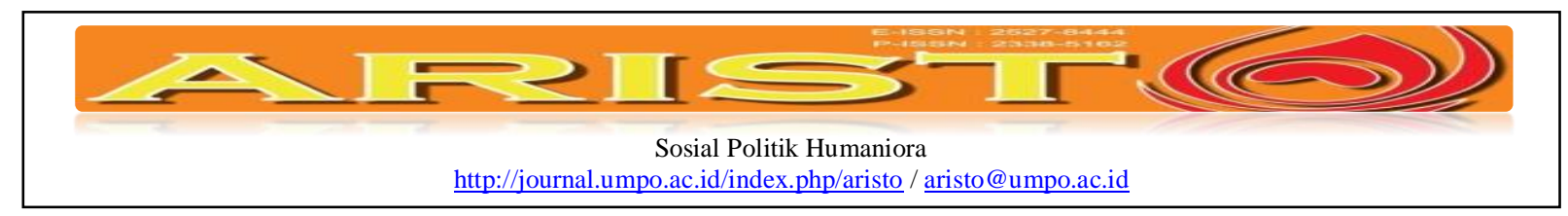

\section{Kesimpulan}

UMKM sentra kerajinan keramik dinoyo memilki beberapa kendala diantaranya yaitu dikarenakan kurangnya pemahaman tentang pemasaran, selain itu kurangnya modal untuk mengembangkan usaha kerajinan keramik, namun dalam hal ini UMKM dapat meminimalisir permasalahan yang terjadi dengan mengupayakan perkembangan UMKM agar dapat berjalan berdasarkan tujuannya. Salah satunya dengan memerdayakan sumber daya manusianya dalam menciptakan ide-ide kreatif dalam mendesain suatu produk, agar dapat menciptakan produkproduk yang baru yang lebih menjual. Namun permasalahan ini juga tidak boleh lepas dari keikut sertaanyya pemerintah untuk membantu permasalahan-permasalahn yang terjadi di UMKM sentra kerajinan keramik Dinoyo, salah satunya mungkin dengan cara memberikan bantuan berupa dana maupun pelatiha-pelatihan untuk para pengrajin keramik, serta mampu memasarkan produk yang dihasilkan. Dikarenakan UMKM merupakan penolong pertumbuhan perekonomian daerah dan juga data meminimalisir angka kemiskinan di daerah sekitar. 


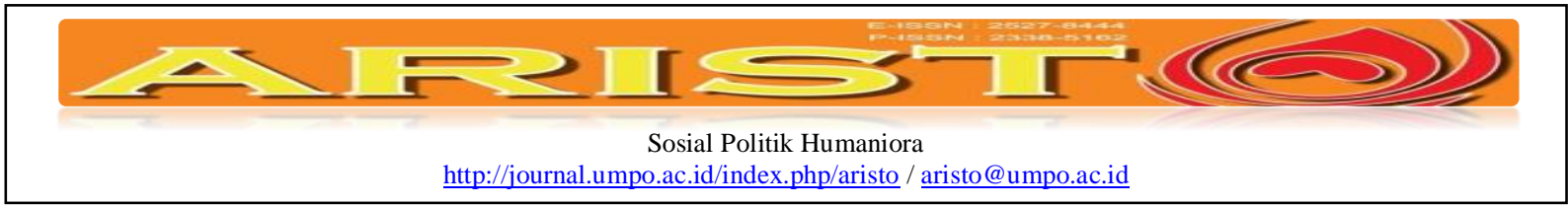

\section{DAFTAR PUSTAKA}

Arief Furchan, Arief. 2007. Pengantar Penelitian dalam Pendidikan. Malang : Pustaka Pelajar.

Miles. Matthew; Michael Huberman. 1994. Qualitative Data Analysis. Arizona state University.

Moleong, lexy. 2012. Metodologi Penelitian Kualitatif. Bandung : PT. Remaja Rosdakarya.

Sugiyono. 2012. Metode Penelitian Pendidikan. Bandung: Alfabeta.

Sutrisno, Hadi. 1986. Metodologi Research, Bandung: UGM.

Susan, Stainback. 1988. Understanding \& Conducting Qualitative Research. Publishing Company.

Undang-Undang Nomor 20 Tahun 2008 Tentang Usaha Miro, Kecil dan Menengah.

Laporan Akuntansi Kinerja Instansi Pemerintah Kota Malang. 